\title{
CORRIGENDUM
}

\section{Prolonged lymphocytopenia after bendamustine therapy in patients with relapsed or refractory indolent B-cell and mantle cell lymphoma}

H Saito, D Maruyama, AM Maeshima, S Makita, H Kitahara, K Miyamoto, S Fukuhara, W Munakata, T Suzuki, Y Kobayashi, $\mathrm{H}$ Taniguchi and K Tobinai

Blood Cancer Journal (2017) 7, e620; doi:10.1038/bcj.2017.100; published online 3 November 2017

Correction to: Blood Cancer Journal (2015) 5, e362; doi:10.1038/ bcj.2015.86

Following the publication of this article, it has come to the authors' attention that the baseline CD4-positive T-cell count range of $83-645 \mu \mathrm{l}$ given in the text was incorrect. The correct range is $83-978 \mu \mathrm{l}$.

The authors wish to apologize for any inconvenience caused. 